\title{
PEDAGOGIKA OGÓLNA A SOCJOLOGIA OGÓLNA
}

Streszczenie: Pedagogika, jako nauka o wychowaniu, oraz socjologia, jako nauka o społeczeństwie, to dziedziny pokrewne. Tradycja w tym zakresie jest zresztą długa. Nie tylko Florian Znaniecki uprawiał refleksję $\mathrm{w}$ ramach obu dyscyplin, lecz wcześniej podobnie czynił Emile Durkheim, ojciec akademickiej socjologii. Podobieństwa dotyczą ujęć teoretycznych oraz pól i kontekstów badawczych. Socjologia ogólna to socjologia teoretyczna, to próba wypracowania ogólnej teorii społeczeństwa. W przypadku pedagogiki aspiracje sięgają chyba nieco dalej, gdyż obejmują jakiś rodzaj metarefleksji nad procesami wychowania w społeczeństwie, który jest dodatkowo wyposażony w imperatyw metodologiczny, a także rozważania na temat kondycji współczesnego człowieka. Autor próbuje zanalizować status obu „ogólnych” dziedzin występujących w ramach dwóch dyscyplin nauk społecznych w kategoriach podobieństw, różnic, a nawet integracji w ramach wybranych zagadnień.

Słowa kluczowe: teoria, pedagogika ogólna, socjologia ogólna, metodologia nauk społecznych.

\section{Wprowadzenie}

Ogólność to termin, który ma wprawdzie ustalone znaczenie - tak w języku, jak i w nauce, niemniej jego konotacje potoczne są na tyle wpływowe, że przenikają do sfery refleksji naukowej w różnych zresztą dyscyplinach: socjologii, pedagogice, psychologii, ekonomii itp. A myśl obiegowa skłonna jest ogólność łączyć z nieokreślonością, niedookreśleniem, ogólnikowością. Zatem gdyby odwołać się jedynie do językowego rozumienia terminów „ogólny” i „ogólność”, to dostrzeżemy, że wiąże się je z ogółem, całokształtem, wielością. Można by więc stwierdzić, że stosowanie się do znaczeń przypisywanych określonym słowom w ojczystym języku byłoby w tym wypadku wystarczające dla sprawnego komunikowania się.

Rzeczywistość, w tym ta naukowa, jest jednak bogatsza. W tym przynajmniej sensie, że nadaje ogólności również inne znaczenia, czyniąc z niej kategorię wieloznaczną. Skoro tak, to można powiedzieć, że należałoby trzymać się logicznych 
określeń ogólności. A jest tu ona określana jako możliwość wyprowadzenia z danego twierdzenia inferencyjnych konsekwencji (por. Kmita 1975). Oznacza to, że twierdzenie ogólne, a co za tym idzie, teoria ogólna, pozwala nam odnosić je do rozmaitych zjawisk i procesów społecznych, edukacyjnych, kulturowych, ekonomicznych itp. Innymi słowy, zarówno teoretyk, jak i badacz-empiryk mogą uczynić z teorii sprawne narzędzie analizy rzeczywistości, ponieważ ogólność to nie ogólnikowość, lecz - przeciwnie - możność wyprowadzenia kolejnych twierdzeń, które można by nazwać roboczo „stosowanymi”.

W niniejszym opracowaniu stawiam dwie tezy. Pierwsza z nich odnosi się do faktu, że dwie tytułowe subdyscypliny: socjologię ogólną oraz pedagogikę ogólną łączy nawet więcej aniżeli socjologię i pedagogikę jako nauki społeczne. Spoiwem jest tu ogólna teoria społeczna, której wypracowaniem, w różnym wprawdzie zakresie, zajmują się obie subdyscypliny. Czynią to od dawna, zresztą wzajemnie do siebie nawiązują oraz pozostają w czynnym kontakcie z innymi dyscyplinami nauki oraz ich subdyscyplinami.

Ponadto tak na gruncie socjologicznym, jak i pedagogicznym - budowanie teorii ogólnej łączy się z myślą klasyczną (por. Swedberg 2014; Banaszak 2006, 2011; Śmietańska 2016). Rozumiem przez nią teorie, koncepcje lub - czasami - pomysły teoretyczne, które prócz szlachetnej patyny czasu, posiadają walor zgodności z rzeczywistością, trafności i przydatności w analizach współczesnych zjawisk i procesów społecznych. W tym sensie teoretyzowanie wymaga dobrego przygotowania, a także czasu poświęconego na samodzielną lekturę dzieł klasyków i dzieł współczesnych badaczy (por. Ritzer 2004). Zastępowanie samodzielnej lektury opracowaniem podręcznikowym czy tzw. obiegową prawdą naukową prowadzi do pojawiania się w naukowych dziełach widziadeł, cieni (Platon) rzeczywistych idei.

Druga teza jest związana z imperatywem dyskusji oraz multidyscyplinarnym charakterem obu subdyscyplin. Dyskusja to zdolność do stosowania siły argumentów, a nie argumentów siły w naukowym sporze. A także, jak mawiał Piotr Skarga, wyzbycia się przywar właściwych nieprzyjaciołom mądrości, tj. myślenia wyłącznie własną głową oraz myślenia wyłącznie cudzą głową. Pomóc może w tym posługiwanie się w myśleniu typami idealnymi.

Tym samym multidyscyplinaryzm sprowadza się nie tylko do powoływania się na dorobek innych dyscyplin nauki, lecz wyraża się przede wszystkim w umiejętności syntetyzowania różnych ujęć (por. Tarkowska 2010; Gnitecki 2004). W tym znaczeniu może stanowić jedynie wstęp do tworzenia własnych ujęć i koncepcji. Przekraczanie granic nie może bowiem oznaczać ignorancji. Wkraczanie na pole badawcze innej dyscypliny naukowej jest więc w dosłownym rozumieniu niemożliwe. Jest natomiast możliwe, a nawet wielce wskazane, rozumne korzystanie z dorobku innych nauk. Pojmuję to jako proces, na który się składają: zrozumienie, przetworzenie, analiza, krytyka, sprowadzenie do tworzywa dla własnych celów teoretycznych bądź empirycznych, uformowanie w postaci zmodyfikowanej. 


\section{Ogólna socjologia i ogólna pedagogika. O pewnym typie pokrewieństwa}

Pokrewieństwo między socjologią i pedagogiką jest oczywiste. Wydaje mi się jednak, że między socjologią ogólną a pedagogiką ogólną jest ono jeszcze bliższe. Mam na myśli fakt, że obie subdyscypliny nie tylko odwołują się do tych samych zasobów wiedzy, lecz przede wszystkim to, że przedmiotem refleksji, wspólnie, czynią teorię (Gnitecki 2004). Spróbujmy więc przeanalizować, w jaki sposób definiują to, czym się zajmują.

Dzięki staraniom Janiny Kostkiewicz (por. 2017) możemy dziś analizować przenikliwą myśl społeczną Andrzeja Niesiołowskiego (2017, s. 96), który tak definiuje pedagogikę ogólną: „Pedagogika ogólna (która jest przedmiotem naszych rozważań), to syntetyczna nauka poznawczo-normatywna w ogólnych, niezależnych od przypadkowości czasowo-przestrzennej faktach, prawach, celach, formach i metodach świadomego i mimowolnego wychowania i samowychowania z punktu widzenia jednostki i grupy".

Zacznę od tego, że w tej definicji zmieniłbym tylko jedno słowo. Otóż „prawo” zastąpiłbym „prawidłowością”. Jest to związane z ogólną charakterystyką nauk społecznych. Prawa w znaczeniu ścisłym w ogóle tu nie występują: ani w pedagogice, ani w psychologii, ani w etnologii, ani też w socjologii czy ekonomii. Poza tym propozycję Niesiołowskiego uznaję za bardzo trafną. Z kilku względów. Po pierwsze: wskazuje on na ponadczasowy charakter twierdzeń formułowanych na gruncie tej subdyscypliny. Można tę tezę sprowadzić np. do pojęcia wielofunkcyjności Georga Simmla (1997). Po wtóre, autor, jako socjolog i pedagog, w sposób jednoznaczny wskazuje na punkt widzenia grupowy oraz jednostkowy. Łączy więc, w pewnym sensie, perspektywę socjologiczną z pedagogiczno-psychologiczną.

Warto także odnieść się do myśli, którą Andrzej Niesiołowski „wyrzuca” do przypisu. Jest to ciekawa dyskusja z poglądami Zygmunta Mysłakowskiego oraz Sergiusza Hessena. Niesiołowski (2017, s. 96) stwierdza, że „strona normatywna stanowi sens i cel istotny pedagogiki jako nauki”. Zwraca przy tym uwagę, że o ile w pracach Mysłakowskiego teza ta nie jest wystarczająco podkreślona, to w Podstawach pedagogiki Hessena znajduje ona należyte miejsce w strukturze analiz polskiego filozofa i pedagoga. Całość odzwierciedla stanowisko Niesiołowskiego w sprawie ocen formułowanych przez pedagogikę - zarówno systematyczną, jak i ogólną (por. też 2017, tabela 1, s. 97).

Podobnie rzecz się ma z socjologią ogólną. Jest ona związana $\mathrm{z}$ teorią, teoretyzowaniem, uogólnianiem oraz konfrontowaniem idei z rzeczywistością (por. Swedberg 2016, 2014; Kozyr-Kowalski 2003; Durkheim 200o), w myśl zasady, że najbardziej praktyczna jest dobra teoria. I tu właśnie chcę podzielić pogląd, że bardziej trafne jest nazywanie socjologii ogólnej socjologią teoretyczną. Rzeczywiście, ta pojęciowa dystynkcja wydaje się być kluczem do zrozumienia statusu omawianej subdyscypliny, a także ugruntowania jej statusu. Dodatkowo, zadaję pytanie, czy nie byłoby warto rezultatów wspomnianej dyskusji oraz aktualnego stanu 
rzeczy wykorzystać na pedagogicznym gruncie? Według mnie tak, jeśli nawet nie w bezpośredniej formie, to na pewno jako nieustanne podkreślanie teoretycznego charakteru pedagogiki ogólnej po to, aby nie było wątpliwości, jakie są jej cele.

Wracając jednak do właściwych socjologii ogólnej/teoretycznej spraw, warto podkreślić, iż jej teoretyczne umocowanie, a także - co nie pozostaje bez znaczenia - ukierunkowanie na tworzenie ogólnej teorii społeczeństwa, stałą kontrolę twierdzeń oraz kategorii, którymi dysponuje, stało się wyróżnikiem oraz buduje jej status quo. Jak ujmuje to Stanisław Kozyr-Kowalski (2003, s. 20-22; por. też Banaszak 2017), myślenie teoretyczne związane jest $z$ dodatkowym elementem strukturalnym, który nazywamy „globalną strukturą teoretyczną”. Składają się na nią: ontologia społecznego świata, epistemologia życia społecznego, cząstkowe teorie ontologiczne i epistemologiczne, wreszcie teorie idiograficzne oraz doktryny praktyczne. Najistotniejsze dla budowania teorii ogólnej są: ontologia oraz epistemologia życia społecznego. Zatem od czasów Comte’a teoria budowy, funkcjonowania i zmiany społeczeństwa stanowi punkt wyjścia dla wszelkiej refleksji społecznej. Warto w tym miejscu również podkreślić, że analogiczną sytuację spotykamy w pedagogice. I to nie tylko w odniesieniu do pewnego modelu postępowania, lecz nawet do treści, gdyż odwołuje się ona dokładnie do tych samych teorii, koncepcji lub jedynie pomysłów teoretycznych.

\section{Typy idealne a teoretyzowanie w socjologii i pedagogice}

Typ idealny to koncepcja metodologiczna Maxa Webera (1985), upraszczana i deformowana przez lata. Ortodoksyjna (czyli w zgodzie ze starogreckim źródłosłowem „zgodna z rzeczywistością”) analiza myśli Weberowskiej wiąże typy idealne z jedną $\mathrm{z}$ realnych tendencji występujących w strukturze nowoczesnych społeczeństw. Tendencja ta może mieć w pewnych krajach, okolicznościach i czasie charakter dominujący lub może wyrażać zjawiska przeciętne. Wówczas typ idealny przybierze postać typu dominującego albo przeciętnego.

Danemu pojęciu, kategorii nie przysługuje nigdy przymiot tendencji jedynej, która ogarnia wszystko i wszystkich. Nigdy więc nie jest tendencją absolutną. Należy typ idealny pojmować relacyjnie oraz wieloefektywnie. Oznacza to, że zwykle różnorako oddziałuje na ludzi i ich społeczne światy. Analizy na gruncie pedagogiki ogólnej i socjologii ogólnej mieszczą się w pojęciu typów idealnych, tendencji dostrzeżonych przez badaczy. Szacowanie czy tendencje te są dominujące, czy przeciętne, stanowi zadanie dla nauk stosowanych (lub subdyscyplin tych nauk zajmujących się stosowaniem wiedzy).

Rozumowanie w kategoriach typów idealnych, czyli pewnych realnych konstruktów, których „obowiązywanie” ma różny wymiar, tj. od nikłej, ledwie zauważalnej tendencji aż po tendencję dominującą, stanowi podstawę budowania teorii ogólnej. Może więc stać się częścią wspólną dla socjologii oraz pedagogiki. Zresztą pewne fragmenty owej „części wspólnej” są - można by tak powiedzieć - immanentnie 
wspólne, z racji odniesień do tego samego przedmiotu i obiektu refleksji. Tak czy inaczej teoretyczność obu dyscyplin, która stanowi dla mnie fakt, może być zapośredniczona poprzez wspólną „metodę” typów idealnych.

Prócz koncepcji Maxa Webera warto także powrócić do tez i mott obecnych w myśli poprzedników niemieckiego socjologa. „Prawda jest trójjedynością” ten aforyzm oznaczał dla Hegla, iż nie jest możliwa prawdziwa wiedza o jakiejś teorii lub rzeczywistości bez samodzielnej drogi od tezy, przez antytezę, aż do syntezy. Synteza jest tu rozumiana jako „dobro intelektualne, w którym zostają zachowane, rozwinięte i doprowadzone do nowego punktu cząstkowe prawdy zawarte w tezie i antytezie" (Kozyr-Kowalski 2005, s. 11). To bardzo blisko typu idealnego, teorii w ogóle i teoretyzowania jako procesu intelektualnego. Dodajmy do tego Maxa Schelera (1990) „zgodność sensową" (Sinnentsprechung), rozumianą jako samodzielne i niezależne dojście do takich tez i kategorii, które wcześniej ktoś już wypowiedział, a otrzymamy całkiem ciekawy zestaw do „teoretycznego eksperymentowania".

Kolejnym łączącym obie dyscypliny nauki faktem jest wieloparadygmatyczność socjologii i pedagogiki. Zdaniem Thomasa Kuhna (1968), wieloparadygmatyczność nie jest ani specyfiką, ani zjawiskiem negatywnym. Wskazywał on na słabe strony nauk monoparadygmatycznych. Polski socjolog Janusz Ziółkowski stawiał z kolei tezę, iż socjologia jest jedna nie mimo wielu różnych socjologii, lecz dzięki temu, że jest wiele różnych socjologii.

Tę tezę można zuniwersalizować i stosować wobec innych dyscyplin, w tym pedagogiki. Podobnie można by poddać uniwersalizacji kolejną tezę Janusza Ziółkowskiego (1997, s. 533), który wyliczając impulsy i bariery rozwoju socjologii, przekonywał, że wszechobecność w socjologii amerykańskiej takich pojęć, jak «pionier», «nowe pojęcia», «zaniedbana dotąd dziedzina badań», «pierwsza poważna próba», «odkrycie» nie jest niczym innym, jak wyrazem pozornych wynalazków, amnezji intelektualnej i kompleksu odkrywcy. Polski uczony łączył ten stan rzeczy z kształceniem akademickim socjologów, w którym niewiele pozostaje miejsca dla szerokiej kultury humanistycznej oraz dla historii myśli socjologicznej. Kilka lat przed polskim socjologiem bardzo podobną diagnozę stawiał Peter L. Berger (1995), autor słynnego Invitation to Sociology. Posługuje się on określeniem barbarzyństwa współczesnej socjologii, gdy stwierdza poważne luki w historycznym i filozoficznym wykształceniu socjologów.

Niemniej jednak prócz wskazywania na słabe strony oraz mankamenty współczesnych prac socjologicznych i pedagogicznych, warto przywołać te, które są ze wszech miar „dobrą robotą” teoretyczną. Taką właśnie próbą wyprowadzenia ogólnej teorii wychowania z koncepcji Niklasa Luhmanna są znakomite, oparte na samodzielnej i wnikliwej analizie oryginalnych prac niemieckiego socjologa, prace Michała Głażewskiego (2012, s. 146; por. też 2010), który stwierdza na przykład, że: „Intencje i skutki działania wychowawczego nigdy nie są identyczne - być może na szczęście dla wychowanka. Wychowanie w rzeczywistości stanowi ofertę: 
dziecko do procesu wychowania wnosi własne dyspozycje psychofizyczne, własne prawidłowości ontogenetyczne, własne doświadczenia, idiosynkrazje i skłonności”. Można tę myśl autora traktować jako przykład twierdzenia ogólnego, jako części teorii ogólnej.

\section{Instytucjonalizacja subdyscyplin akademickich w Polsce}

Tytułem uzupełnienia rozważań na temat teoretyczności socjologii ogólnej oraz pedagogiki ogólnej, warto wstępnie przeanalizować procesy instytucjonalizacji omawianych subdyscyplin w polskim systemie szkolnictwa wyższego. Jak się wydaje, większość dyscyplin nauki, subdyscyplin, a nawet prądów, nurtów czy szkół wykazuje tendencję do instytucjonalizacji. Proces ten będę rozumiał klasycznie za Thorsteinem Veblenem (1978) oraz Johnem R. Commonsem. Ten ostatni podaje nieco inną definicję instytucji, którą traktuje jako „podlegające kontroli działanie zbiorowe" (Commons 1931, s. 648-657), niemniej jednak obaj przedstawiciele amerykańskiego instytucjonalizmu są zgodni, że to właśnie instytucje są najważniejszymi „podmiotami” nowoczesnych społeczeństw. Podobnie w przypadku uniwersytetów, katedr i zakładów, całych dyscyplin oraz subdyscyplin akademickich.

I na tym poprzestanę, ponieważ nie chcę w tym miejscu odwoływać się do genezy instytucjonalizacji obu nauk, tj. socjologii i pedagogiki. Muszę jednak zauważyć, że w Europie narodziny akademickiej socjologii odbyły się przy udziale pedagogiki, za sprawą Emila Durkheima, który w 1895 roku powołał do życia pierwszą w Europie katedrę socjologii. Jednakże jej pełna nazwa brzmiała: Katedra Socjologii i Pedagogiki. Nawet później, gdy w 1902 roku przeniósł się na paryską Sorbonę, pedagogika wciąż pozostawała w nazwie katedry.

Nie może być więc wątpliwości, że socjologia i pedagogika to pokrewne dziedziny, siostry w ramach nauk społecznych. Zresztą fakt, że nauki te za obiekt biorą społeczeństwo, jest tyleż bezsporny, co banalny. Warto jedynie podkreślić, że socjologia aspiruje do objęcia możliwie wielu aspektów funkcjonowania społeczeństwa, z kolei pedagogika skupia się na zjawiskach i procesach wychowawczych oraz socjalizacyjnych. Rzecz jednak nie w tym, aby wskazywać na różnice czy podobieństwa obu pełnoprawnych dyscyplin nauki, lecz aby wskazać na ich elementy swoiste. Tak czynił zarówno Durkheim (1968/1922) w książce o edukacji i pedagogice, jak i Florian Znaniecki (2001) w napisanej jeszcze w „okresie poznańskim" dwutomowej pracy na temat socjologii wychowania.

Tym samym można by przyjąć, że subdyscypliny tych nauk - odpowiednio: socjologię ogólną oraz pedagogikę ogólną również cechuje wiele podobieństw. Tak właśnie uważam, mimo że rozwój tych subdyscyplin następował w nieco odmienny sposób. Na pedagogikę silniej oddziaływały np. uwarunkowania społecznej, edukacyjnej i politycznej rzeczywistości (por. Przyszczypkowski 2012, s. 40-41; por też. Hejnicka-Bezwińska 2008), stąd w Polsce instytucjonalnie zanikła ona w okresie po 1945 roku. Socjologia wprawdzie nie oparła się ideologicznym wstrząsom, a nawet 
„likwidacji” jako kierunku studiów, niemniej socjologia ogólna, rozumiana jako pewien typ refleksji o zjawiskach i procesach społecznych, wciąż była obecna w publikacjach jej przedstawicieli.

Przechodząc jednakże nad tym, literalnie trzymając się pojęć instytucji oraz instytucjonalizacji, warto wskazać na fakt, iż obecnie obie subdyscypliny, pedagogika ogólna i socjologia ogólna są obecne w strukturze naukowej i dydaktycznej polskich uniwersytetów. Katedry oraz zakłady naukowe, w których rozwija się teorię ogólną, są dziś częścią wszystkich liczących się jednostek naukowych. Nie ma tu znaczących różnic pomiędzy obiema dyscyplinami. Z kolei podobieństwa dotyczą np. umiejscowienia zakładów socjologii ogólnej i pedagogiki ogólnej w strukturach uczelni technicznych, rolniczych, ekonomicznych itp. Otóż wszędzie tam, gdzie pełnią one tzw. funkcję usługową, noszą w nazwie „ogólność”. Rzecz jasna, w takim wypadku trudno jest mówić o rozwijaniu teorii ogólnej, lecz o umownym określeniu tych jednostek mianem ogólnych.

Już wstępna analiza miejsca i roli jednostek rozwijających teorię ogólną czy to na pedagogicznym, czy socjologicznym gruncie, pozwala jednakże dostrzec dwie różnice. Pierwsza z nich to tendencja do łączenia pedagogiki ogólnej z metodologią dyscypliny, a nawet $z$ metodyką badań empirycznych. W socjologii taka tendencja raczej nie występuje i mamy do czynienia $\mathrm{z}$ wyraźnym wydzieleniem się katedr i zakładów metodologicznych jako odrębnych bytów instytucjonalnych. Druga różnica dotyczy natomiast obecności zakładu socjologii teoretycznej w strukturze Instytutu Filozofii i Socjologii Polskiej Akademii Nauk, zakładu ważnego i od lat rozwijającego teorię ogólną. Różnica ta sprowadza się po prostu do nieobecności pedagogiki jako nauki w strukturze instytutów PAN.

Na podstawie nawet pobieżnej analizy można więc wnosić, iż refleksja natury ogólnej lub uogólniającej, która oparta jest na analizie klasycznych oraz współczesnych teorii, koncepcji lub jedynie pomysłów teoretycznych, i konfrontowana z materiałem faktograficznym konfirmującym bądź dyskonfirmującym określone twierdzenia jest niezbywalnym elementem obu naukowych dyscyplin. Tu już bardzo blisko stwierdzenia, że jakaś forma teoretycznej refleksji, uprawiana systematycznie i w oparciu o określony model analityczny czy metodologiczny, jest domeną każdej nauki. Przywołam tu jedynie fizykę teoretyczną (por. Boas 2006; Hawking 1990).

Jest ona dobrym przykładem relacji między empiryzmem a uogólniającą refleksją, wykorzystującą język matematyki. Dodatkowo, okraszona jest hipotezą, czyli propozycją twierdzenia, które jeszcze nie zostało potwierdzone empirycznie. Innymi słowy, fizycy eksperymentalni, wychodząc od twierdzeń teoretycznych, przeprowadzają badania, których rezultaty potwierdzają tezy teoretyczne oraz je w jakimś stopniu modyfikują. Z kolei fizycy teoretyczni, za pomocą metod matematycznych, opisują świat przyrody oraz „eksperymentują” myślowo - proponując nowe twierdzenia. Te nowe twierdzenia podlegają z kolei empirycznemu potwierdzeniu przez fizyków eksperymentalnych. 
Taki model postępowania jest, jak mi się wydaje, uniwersalny. Nie inaczej postępują przecież nauki społeczne, analizowane tu: socjologia i pedagogika (por. też Rubacha 2008, s. 162-164), a także np. ekonomia. Jak stwierdza Grażyna Musiał (2008, s. 117): „Od każdej teorii naukowej oczekuje się, że jest zdolna do wyjaśniania danej klasy obiektów i niezawodna w przewidywaniu przyszłości. Oczekuje się również, że zawiera ona arsenał instrumentów umożliwiających poznawanie nowych tendencji, które są dopiero na etapie stawania się formułują się i utrwalają". I dalej: „Ekonomia zabiega o prawdę w sensie korespondencji z rzeczywistością. Nosicielami prawdy wysoce informatywnej, tj. bogatej w treść i wysoce sprawdzalnej, są prawa uniwersalne oraz teorie. Te prawa i teorie muszą być powszechne, tj. mówić o wszystkich czasoprzestrzennych wymiarach świata. Struktury i relacje opisywane przez teorię wyjaśniającą muszą być w takim czy innym sensie głębsze od własności wyjaśnianych. Co prawda, słowo „głębszy” wymyka się wszelkim próbom wyczerpującej analizy logicznej, ale może ono służyć jako przewodnik naszym intuicjom. Głębia teorii naukowej jest ściśle związana z jej prostotą oraz bogactwem zawartości” (Musiał 2008, s. 118). Rzeczywiście, gdyby ową „głębię”, w połączeniu z powszechnością, zastąpić ogólnością w naszym, zaczerpniętym od Georga Simmla (1997) rozumieniu, to okazałoby się, że mówimy dokładnie o tym samym, mimo reprezentowania różnych dyscyplin naukowych. Można by więc wrócić do tezy o jedności w obrębie metodologii nauk społecznych jako całości, ponieważ dyscyplinarne różnice to jedynie odcienie tego samego koloru.

\section{Zakończenie}

Socjologia teoretyczna oraz pedagogika ogólna to bardzo zbliżone co do celu oraz przedsiębranych środków subdyscypliny. Obie aspirują do zbudowania ogólnej teorii społecznej. Socjologia w najszerszym wymiarze, pedagogika w odniesieniu do procesów wychowania i socjalizacji. Można więc założyć, iż prócz podobieństw w zakresie celów, metodyki pracy, generalizacji i formułowania uogólnień da się również wskazać na analogiczne schorzenia, które dotykają analizowane subdyscypliny (por. Banaszak 2017).

Kilka z nich ma wybitnie współczesny charakter. Zarówno na socjologicznym, jak i pedagogicznym gruncie można bowiem mówić o separacji teorii i empirii prowadzących do wzajemnej izolacji. Dodatkowo, teorię się dziś instrumentalizuje, zrywając przez to więzi łączące ją z praktyką. Z kolei badania empiryczne i ich rezultaty przeszacowuje się i absolutyzuje, spychając jednocześnie teorię i teoretyzowanie na boczny tor. Wreszcie, w związku z redukowaniem wszystkiego do pędu i stawania się, poszukuje się wciąż nowych i nowocześnie brzmiących kategorii. Ta próba wyjścia naprzeciw presji absolutnych nowości przyczynia się do wyścigu kategorii, czego ubocznym skutkiem jest wieloznaczność i niedookreśloność fundamentalnych pojęć (Banaszak 2017, s. 92-93). 
Co jednak ważniejsze, obie subdyscypliny mogą się poszczycić trafnymi oraz ciekawymi ujęciami rzeczywistości społecznej w jej różnych wymiarach. Ujęcia te można z powodzeniem nazywać teoretycznymi, gdyż zwykle zmierzają ku próbie zbudowania teorii ogólnej lub - używając klasycznego określenia - posługują się typami idealnymi w analizach zjawisk i procesów społecznych, edukacyjnych, kulturowych, ekonomicznych itd. Tak rozumiana teoria ogólna jest bardzo potrzebna, tak w empirycznych próbach potwierdzania faktów społecznych (Durkheim 2000), jak i w pedagogicznych aplikacjach określonych rozwiązań.

\section{Bibliografia}

Banaszak S. (2017). Teoria i empiria - kilka uwag metodologicznych i praktycznych. W: Kubinowski D., Chutoriański M. (red.). Pedagogika jako humanistyczno-społeczna nauka stosowana: konsekwencje metodologiczne. Kraków: Oficyna Wydawnicza „Impuls”.

Banaszak S. (2011). Edukacja menedżerska w społeczeństwie współczesnym. Studium teoretyczno-empiryczne. Poznań: Wydawnictwo Naukowe UAM.

Banaszak S. (2006). Menedżerowie w strukturze społecznej. Poznań: Wydawnictwo WSKiZ.

Boas M. L. (2006). Mathematical Methods in the Physical Sciences. Danvers: John Wiley \& Sons.

Commons J. R. (1931). Institutional Economics. „American Economic Review”, vol. 21.

Durkheim É. (200o). Zasady metody socjologicznej, tłum. J. Szacki. Warszawa: Wydawnictwo Naukowe PWN.

Durkheim É. (1968/1922). Éducation et socjologie. Paris: Les Presses universitaires de France.

Głażewski M. (2012). Socjalizacja i edukacja w teorii systemów autopojetycznych Niklasa Luhmanna. „Forum Socjologiczne”, nr 2.

Głażewski M. (2010). Dystopia. Pedagogiczne konteksty teorii systemów autopojetycznych Niklasa Luhmanna. Zielona Góra: Oficyna Wydawnicza Uniwersytetu Zielonogórskiego.

Gnitecki J. (2004). Pedagogika ogólna z metodologią. Poznań: Wydawnictwo Naukowe Polskiego Towarzystwa Pedagogicznego.

Hawking S. (1990). Krótka historia czasu. Od wielkiego wybuchu do czarnych dziur, tłum. P. Amsterdamski. Warszawa: Wydawnictwo „Alfa”.

Hejnicka-Bezwińska T. (2008). Pedagogika ogólna. Warszawa: Wydawnictwa Akademickie i Profesjonalne.

Hejnicka-Bezwińska T. (2013). Tożsamość pedagogiki w warunkach „wielkiej zmiany kulturowej”. „Rocznik Pedagogiczny”, nr 36.

Hejnicka-Bezwińska T. (2005). „Ogólność” we współczesnym myśleniu o pedagogiach. „Kwartalnik Pedagogiczny”, nr 5. 
Kmita J. (1975). Wykłady z logiki i metodologii nauk. Warszawa: PWN.

Kostkiewicz J. (2017). Wprowadzenie. Zarys pedagogiki ogólnej Andrzeja Niesiołowskiego - o koncepcji i jej rękopisie powstałym $w$ niemieckich oflagach. W: Niesiołowski A. Zarys pedagogiki ogólnej. Rękopisy z oflagu. Kraków: Wydawnictwo Uniwersytetu Jagiellońskiego.

Kostkiewicz J. (2015). O potrzebie badań nad polska myśla pedagogiczna - obszary zaniechane, obszary wymagajace reinterpretacji. W: Gola B., Jagielska D. Kostkiewicz J. (red.). Niepodległościowe koncepcje i programy wychowania przełomu XIX i XX wieku. Kraków: UJ, dostępny na: http://ruj.uj.edu.pl (otwarty: 15.10 .2017$)$.

Kotarbiński T. (1961). Elementy teorii poznania, logiki formalnej i metodologii nauk. Wrocław-Warszawa-Kraków: Ossolineum.

Kozyr-Kowalski S. (2005). Uniwersytet a rynek. Poznań: Wydawnictwo Naukowe UAM.

Kozyr-Kowalski S. (2003). Dwa paradygmaty socjologii neoklasycznej. Wprowadzenie do ksiazzki P. Wechty Socjologia i kryptosocjologia Josepha Aloisa Schumpetera. Poznań: Wydawnictwo Naukowe UAM.

Kuhn Thomas S. (1968). Struktura rewolucji naukowych, tłum. H. Ostromęcka. Warszawa: PWN.

Kwieciński Z. (2011). Pedagogizm - wariacje wokół rozumienia kategorii. „Przegląd Pedagogiczny", nr 1.

Merton Robert K. (1982). Teoria socjologiczna $i$ struktura społeczna, tłum. E. T. Morawska, J. Wertenstein-Żuławski. Warszawa: Wydawnictwo Naukowe PWN.

Musiał G. (2008). Z punktu widzenia ekonomii. Katowice: „Śląsk” Wydawnictwo Naukowe.

Niesiołowski A. (2017). Zarys pedagogiki ogólnej. Rękopisy z oflagu, oprac. Kostkiewicz J. Kraków: Wydawnictwo Uniwersytetu Jagiellońskiego.

Nowak S. (1970). Metodologia badań socjologicznych. Warszawa: Wydawnictwo Naukowe PWN.

Popper K.R. (1965). Unity of Method in the Natural and Social Sciences. W: Braybrooke D. (red.). Philosophical Problems of the Social Sciences. New York: Macmillan.

Petrażycki Leon, 1959, Wstęp do nauki prawa i moralności. Podstawy psychologii emocjonalnej, Warszawa: PWN.

Przyszczypkowski K. (2012). Polityczność (w) edukacji. Poznań: Wydawnictwo Naukowe UAM.

Ritzer G. (2004). Klasyczna teoria socjologiczna, tłum. H. Jankowska. Poznań: Zysk i S-ka.

Rubacha K. (2008). Metodologiczna struktura przedmiotu badań pedagogiki. W: tenże (red.). Konceptualizacje przedmiotu badań pedagogiki. Kraków: „Impuls”.

Simmel G. (1997). Filozofia pieniądza, tłum. A. Przyłębski. Poznań: Wydawnictwo Fundacji Humaniora. 
Scheler M. (1990). Problemy socjologii wiedzy, tłum. S. Czerniak. Warszawa: PWN. Swedberg R. (2016). Before Theory Comes Theorizing or How to Make Social Science More Interesting. „The British Journal of Sociology”, vol. 67, issue 1.

Swedberg R. (2014). The Art of Social Theory. Princeton: Princeton University Press. Śmietańska J. (2016). Talent menedżerski w oświacie. Poznań: Wydawnictwo Naukowe UAM.

Tarkowska E. (2010). Interdyscyplinarność i socjologia. „Rocznik Pedagogiczny” nr 33.

Turner J. H. (2012). Struktura teorii socjologicznej, tłum. G. Woroniecka i in. Warszawa: Wydawnictwo Naukowe PWN.

Veblen T. (1978). The Theory of Business Enterprise. New Brunswick N. J.: Transaction Books.

Weber M. (1985). Obiektywność poznania w naukach społecznych. W: Chmielecki A. (oprac.). Problemy socjologii wiedzy. Warszawa: PWN.

Ziółkowski J. (1997). Impulsy i bariery rozwoju socjologii. W: Kozyr-Kowalski S., Przestalski A., Włodarek J. (red.). Krytyka rozumu socjologicznego. Poznań: Zysk i S-ka.

Znaniecki F. (2001). Socjologia wychowania. T. 1 i 2. Warszawa: Wydawnictwo Naukowe PWN.

\section{GENERAL PEDAGOGY AND GENERAL SOCIOLOGY}

Abstract: Pedagogy as a science of human education and sociology as the scientific study of human society are related fields of social sciences. They share a long and rich tradition. Not only did Florian Znaniecki reflect on the two disciplines, but similarly did Emile Durkheim, the father of academic sociology. Similarities apply to theoretical approaches and research fields and contexts. General sociology is simply theoretical sociology, it is an attempt to develop a general theory of society. In the case of pedagogy, the aspirations reach probably a bit further, as they involve some kind of metathought on the processes of education in society, which additionally is endowed with a methodological imperative, as well as reflections on the condition of modern man. The author attempts to analyse the status of both "general" disciplines within the two disciplines of social sciences in terms of similarities and differences. The integration of selected issues is revealed.

Key words: theory, general pedagogy, theoretical sociology, methodology of social sciences.

Sławomir Banaszak - dr hab., prof. nadzwyczajny Uniwersytetu im. Adama Mickiewicza w Poznaniu, kierownik Zakładu Metodologii Nauk o Edukacji na Wydziale Studiów Edukacyjnych, socjolog i pedagog, autor pierwszej w Polsce książki o menedżerach w strukturze społecznej (Menedżerowie w strukturze społecznej, 2006) oraz o edukacji menedżerskiej (Edukacja menedżerska w społeczeństwie współczesnym. Studium teoretyczno-empiryczne, 2011), autor licznych publikacji na temat gospodarki (Problemy socjologii 
gospodarki, 2008, wraz z Kazimierzem Doktórem), rynku pracy, menedżerów, socjologii edukacji i metodologii nauk społecznych. Adres do korespondencji: Uniwersytet im. Adama Mickiewicza w Poznaniu, Wydział Studiów Edukacyjnych, Zakład Metodologii Nauk o Edukacji, ul. Szamarzewskiego 89, 60-568 Poznań. Adres e-mailowy: s.ban@uam.edu.pl. 